\title{
A possible territorial or recognition behavior of Leptoglossus zonatus (Dallas) (Heteroptera, Coreidae)
}

\author{
Antônio R. Panizzi ${ }^{1}$ \\ ${ }^{1}$ EMBRAPA, Centro Nacional de Pesquisa de Soja. Caixa Postal 231, 86001-970 Londrina-PR, Brazil. E-mail: panizzi@cnpso.embrapa.br
}

\begin{abstract}
Resumo. Provável comportamento territorial ou de reconhecimento de Leptoglossus zonatus (Dallas) (Heteroptera, Coreidae). O percevejo coreídeo Leptoglossus zonatus (Dallas, 1852) é freqüente na cultura do milho (Zea mays L.) no Brasil e tem sido observado voando e pousando sobre objetos ou pessoas que se aproximam do seu habitat. Durante o mês de janeiro de 1995, estudou-se esse comportamento em lavoura de milho. Os resultados indicaram que os percevejos concentraram-se, de forma crescente, sobre objetos (armadilhas de plástico cilíndricas) introduzidos em seu habitat nas primeiras 24 horas. Gradualmente, entretanto, com o passar do tempo (8 dias), esse provável comportamento territorial ou de reconhecimento diminuiu e tendeu a desaparecer.
\end{abstract}

Palavras-Chave. Coreidae; comportamento de defesa; vôo; Zea mays.

Abstract. The coreid Leptoglossus zonatus (Dallas, 1852) is commonly found in corn (Zea mays L.) fields in Brazil, and it has been observed flying and landing on objects or persons near these fields. During January, 1995, this behavior was studied in corn plantations. Results indicated that the bugs concentrated on objects (plastic cylinders traps) introduced into their habitat and that their number increased during the first $24 \mathrm{hs}$. However, as time passed ( 8 days), this possible territorial or recognition behavior gradually decreased, and tended to disappear.

KEYwORDs. Coreidae; defense behavior; flight; Zea mays.

The coreid Leptoglossus zonatus (Dallas, 1852) has a wide distribution in the Americas (AlLEN 1969), and is reported to feed on several species of cultivated plants (PANIZZi 1989; KUBO \& Batista $\mathrm{F}^{\circ}$ 1992; Matrangolo \& Waquil 1994; Raga et al. 1995; Mitchell 2000).

In Brazil, during the late 1980's and early 1990's, L. zonatus became abundant in corn (Zea mays L.) fields, occurring on this crop from Londrina in Paraná State in the south (latitude $23^{\circ} 18^{\prime} \mathrm{S}$ ), up to Balsas in Maranhão State in the northeast (latitude $7^{\circ} 31^{\prime}$ S) (PANizzi 1989, and unpublished).

In corn fields near Londrina, adult bugs were often observed flying toward and landing on objects or persons nearby or in the corn fields. This suggested the hypothesis of a possible territorial defense or recognition behavior. Therefore, field studies were conducted to evaluate such behavior.

During January 1995, three tests were conducted in the field at the Estação Experimental da Embrapa-Soja in Londrina. In the first test, three objects (plastic green traps - cylinders $\mathrm{h}: 38 \mathrm{~cm} \times 10 \mathrm{~cm}$ in diameter) were each hung on a wood pole, $1.5 \mathrm{~m}$ in height, and separated by $10 \mathrm{~m}$. The traps were used simply as objects upon which the bugs could alight. The poles were set $1.5 \mathrm{~m}$ from the perimeter of the corn field. As the traps were set, the number of $L$. zonatus adults landing on them after 5, 10, 20,40, 80, 160, and $320 \mathrm{~min}$. was recorded. The total number of bugs observed on the traps during days 1,2, 4, and
8, after the traps were set, was also recorded and calculated. When the first test was over, two additional tests were conducted in sequence, in the same place, following the same procedures described for the first test. The total number of insects recorded, at each time within a single day, and during the days $1,2,4$, and 8 , was calculated. A regression analysis on the number of insects (three tests) observed during the different time intervals versus the time, both in minutes and in days, was performed.

Data from these field tests clearly indicated that L. zonatus adults landed on the traps in increasing numbers, after progressive time, during day 1 . Considering the data from the three tests, 10 adults were observed after 5 min.; 18 after 10 min.; and 30 after $20 \mathrm{~min}$. These values progressively increased, up to 115 adults after $320 \mathrm{~min}$. The regression analysis clearly indicated this trend, with a high value for the coefficient of determination $\left(\mathrm{R}^{2}=0.8979\right)$ (Fig. 1A). The regression analysis for the individual tests indicated high values for $\mathrm{R}^{2}$, demonstrating the significant tendency of increase in numbers of bugs according to the time intervals (in minutes) within day 1 (Table I).

After day 1 , and up to day 8 , the number of bugs landing on traps progressively decreased. At the end of the first day, 90 bugs were recorded on the traps; at day 2, 84 bugs were recorded; this trend of decreasing number of bugs with time 
(days) continue, going down to 59 bugs at day 4, and finally, 9 bugs at day 8 . The regression analysis performed showed a high value for the coefficient of determination $\left(\mathrm{R}^{2}=0.9979\right)$, demonstrating the tendency of decrease in number of bugs as time progressed in a daily basis (Fig. 1B). The regression analysis for the individual tests indicated high values for $\mathrm{R}^{2}$ (except for test 3 ), demonstrating a tendency of decrease in numbers of bugs with time passing in days (Table I).

Results of these field tests showed that $L$. zonatus flies from the corn plants and lands on objects introduced in its habitat, possibly characterizing a behavior of territorial defense or recognition. This behavior was also commonly observed with human beings approaching the habitat. Bugs flew to and landed on the body of persons moving or standing near the corn field. As time passed, apparently the bugs got used to the objects introduced in their territory, and "accepted" them as part of their habitat.

Beyond volatile chemicals, visual stimuli are key factors in the process of host-plant selection (FINCH \& COLLIER 2000) and defense. Vision may explain how the bugs quickly detected the objects (plastic traps) placed near their habitat. Also, $L$. zonatus adults are known to produce alarm pheromones (LEAL et al. 1994), and males of several species of coreids produce sexual pheromones (AlDRICH et al. 1993); the bug's behavior of hanging about on prominent objects could be interpreted as an adaptive behavior related to pheromone production. However, because the sex of the bugs observed on the traps was not recorded, it can only be speculated from the present data that these bugs were hanging on these objects with the purpose of chemical communication.

Territorial defense by males has been reported in several species of coreids (Mitchell 1980; FuJISAKi 1981; MiYATAKe 1995, 1997; EBERHARD 1998) and is considered widespread in the family (Mitchell 2000). However, the territorial defense reported by these authors is in a short range, involving male/ female aggressive behaviors, and no data were found in the literature regarding the behavior as here reported.

Several adults were observed missing one of the hind legs, which are known to be used as weapons during male contests

Table I. Regression analysis on the number of Leptoglossus zonatus observed on objects (green plastic traps) as a function of time, within a single day (after several intervals of minutes - 5 to 320 minutes) and between days (1 to 8 days).

\begin{tabular}{ccc}
\hline Test & \multicolumn{1}{c}{ Equation } & $\mathrm{R}^{2}$ \\
\hline $1 *$ & $\mathrm{Y}=4.642+0.00055^{*} \mathrm{X}^{2}$ & 0.992 \\
$2 *$ & $\mathrm{Y}=0.0676+0.000158 * \mathrm{X}^{2}$ & 0.994 \\
$3 *$ & $\mathrm{Y}=3.887-10.2207 / \mathrm{X}$ & 0.916 \\
$1 * *$ & $\mathrm{Y}=61.1642-0.9254 * \mathrm{X}^{2}$ & 0.999 \\
$2 * *$ & $\mathrm{Y}=16.0-0.7214 * \mathrm{X}^{*} \mathrm{Ln}(\mathrm{X})$ & 1.000 \\
$3 * *$ & $\mathrm{Y}=2.8837+33.4666 * \mathrm{e}^{(-\mathrm{X})}$ & 0.736 \\
\hline
\end{tabular}

$* \mathrm{Y}=$ number of insects; $\mathrm{X}=$ time in minutes.

$* * \mathrm{Y}=$ number of insects; $\mathrm{X}=$ time in days.
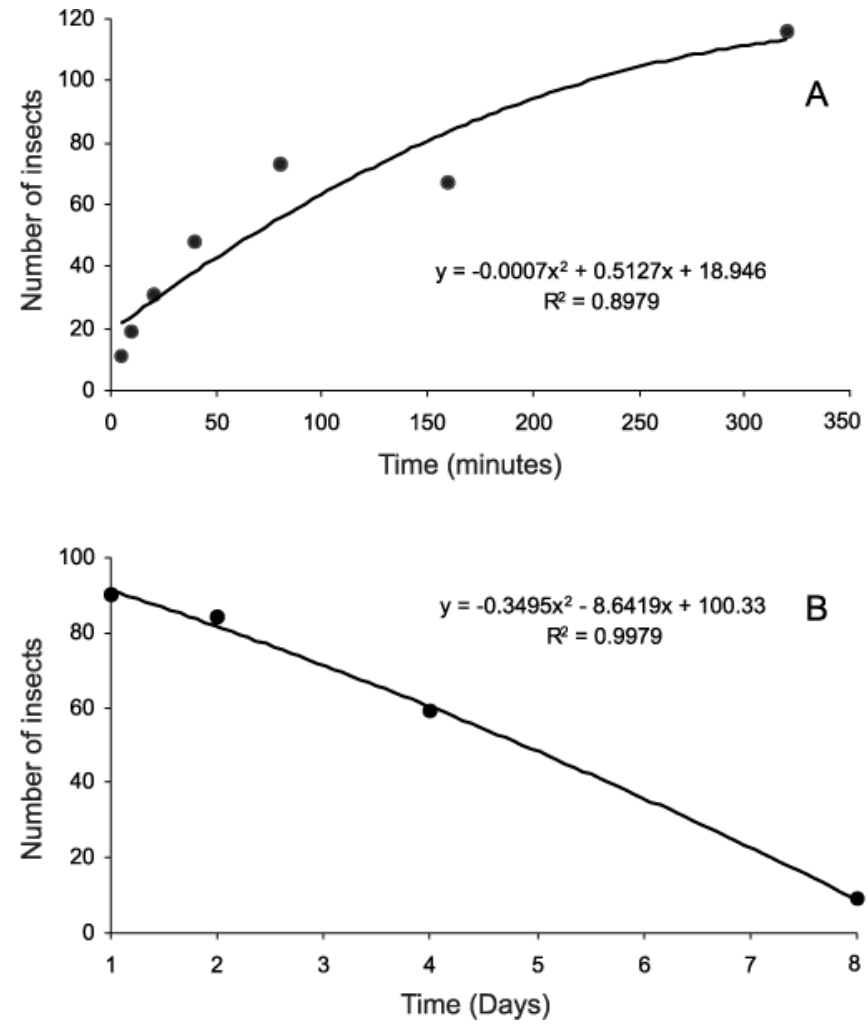

Fig. 1. Total number of Leptoglossus zonatus adults observed on objects (green plastic traps) placed near a corn field, after different time intervals. $\mathrm{A}=$ time interval measured in minutes, up to 320 minutes. $\mathrm{B}$ $=$ time interval measured in days, up to 8 days.

in another species of Leptoglossus (Miyatake 1997). Perhaps, by being large and conspicuous, these legs are easily spotted by predators and, therefore, commonly detached from the bug's body.

In conclusion, this behavior shown by L. zonatus of flying against and landing on objects introduced in its habitat may be used in a way of managing its populations on corn fields. By properly handling objects, bugs can be attracted to concentrate on them and be killed by the use of pesticides on these restricted areas.

Acknowledgments. We thank Jovenil J. Silva for field assistance, and Paula L. Mitchell (Winthrop University, USA), for helpful comments on an early draft of this note. Edson Hirose and Debra Palmquist helped with the statistical analysis, and with editing the figure.

\section{REFERENCES}

Aldrich, J. R.; G. K. Waite; C. Moore; J. A. Payne; W. R. Lusby \& J. P. Kochansky. 1993. Male-specific volatiles from neartic and australasian true bugs (Heteroptera: Coreidae and Alydidae). Journal of Chemical Ecology 19: 2767-2781.

Allen, R. C. 1969. A revision of the genus Leptoglossus Guerin 
(Hemiptera: Coreidae). Entomologica Americana 45: 35-140.

Eberhard, W. G. 1998. Sexual behavior of Acanthocephala declivis guatemalana (Hemiptera: Coreidae) and the allometric scaling of their modified hind legs. Annals of the Entomological Society of America 91: 863-871.

Finch, S. \& R. H. Collier. 2000. Host-plant selection by insects - a theory based on 'appropriate/inappropriate landings' by pest insects of cruciferous plants. Entomologia Experimentalis et Applicata 96: $91-102$.

FuJISAKI, K. 1981. Studies on the mating system of the winter cherry bug, Acanthocoris sordidus Thunberg (Heteroptera: Coreidae). II. Harem defence polygyny. Research Population Ecology 23: 262-279.

Kubo, R. K. \& A. Batista $F^{\circ}$. 1992. Ocorrência e danos provocados por Leptoglossus zonatus (Dallas, 1852) (Hemiptera: Coreidae) em citros. Anais da Sociedade Entomológica do Brasil 21: $467-$ 470 .

Leal, W. S.; A. R. Panizzi \& C. C. Niva. 1994. Alarm pheromone system of leaf-footed bug Leptoglossus zonatus (Heteroptera: Coreidae). Journal of Chemical Ecology 20: 1209-1216.

Matrangolo, W. J. R. \& J. M. Waquil. 1994. Biologia de Leptoglossus zonatus (Dallas, 1852) (Hemiptera: Coreidae) alimentados com milho e sorgo. Anais da Sociedade Entomológica do Brasil 23: 419-423.

Mitchell, P. L. 1980. Combat and territorial defense of Acanthocephala femorata (Hemiptera: Coreidae). Annals of the Entomological Society of America 73: 404-408.

Mitchell, P. L. 2000. Leaf-footed bugs (Coreidae), p. 337-403. In: C. W. Schaefer \& A. R. Panizzi (eds.). Heteroptera of Economic Importance. Boca Raton, CRC Press, $828 \mathrm{p}$.

MiYATAKE, T. 1995. Territorial mating aggregation in the bamboo bug, Notobitus meleagris Fabricius (Heteroptera: Coreidae). Journal of Ethology 13: 185-189.

MiyataKe, T. 1997. Functional morphology of the hind legs as weapons for male contests in Leptoglossus australis (Heteroptera: Coreidae). Journal of Insect Behavior 10: 727-735.

Panizzi, A. R. 1989. Desempenho de ninfas e adultos de Leptoglossus zonatus Dallas (Hemiptera: Coreidae) em diferentes alimentos. Anais da Sociedade Entomológica do Brasil 18: 375-389.

Raga, A.; C. T. Piza JR. \& M. F. Souza Fo . 1995. Ocorrência e danos de Leptoglossus zonatus (Dallas) (Heteroptera: Coreidae) em romã, Punica granatum L., em Campinas, São Paulo. Anais da Sociedade Entomológica do Brasil 24: 183-185. 